\title{
ТЕОРІЯ ІНФОРМАЦІЇ ТА ЇЇ ЗАСТОСУВАННЯ В МЕДИЧНІЙ РЕАБІЛІТАЦІЇ
}

\section{Теорія інформації та її застосування в медичній реабілітації}

\section{В. С. Килівник, В. Л. Смірнова, Н. Я. Панчишин}

Вінницький національний медичний університет імені М. І. Пирогова

Тернопільський національний медичний університет імені І. Я. Горбачевського МОЗ України

Резюме. Розвиток системи ефрективної медичної реабілітації з урахуванням сьогоднішнього рівня громадського здоров'я без сумніву, можна віднести до найважливіших медико-соціальних завдань у сучасній охороні здоров'я. Роль реабілітації у практичній медицині стає все більш значущою. Реабілітацію як процес реалізації комплексу заходів, спрямованих на відновлення соціального і просресійного статусу інваліда, до недавнього часу використовували переважно соціальні служби. Проте в останні десятиліття у зв'язку зі зростанням хронічної патології вона стає більш затребуваною й у медичній галузі.

Мета дослідження - вивчити та узагальнити результати інфрормаціологічних досліджень ефективності медичної реабілітації на біохімічному та біофізичному рівнях.

Матеріали і методи. Використано інформаціологічний метод та математичний апарат теорії інфрормації.

Результати. Зменшення надлишковості створює для біологічної системи небезпеку легкої інформаційної поломки та зриву. При збільшенні передачі інформації надлишковості відбувається зниження швидкості передачі інорормації. Надмірне зростання надлишковості веде до того, що канали перевантажуються надмір ною передачею повідомлень, що зменшує кількість нової інорормації, яку отримує приймач за одиницю часу по даному каналу зв'язку, тому при дуже великій надлишковості система інсрормації втрачає свою ефрективність, лабільність і стає більш інертною.

Висновки. Інформаційні характеристики можна використовувати в якості кількісних критеріїв оцінки есрективності лікування та вибору найоптимальніших методів. Досвід клінічного застосування гальванізаціі та лікарського електрофрорезу свідчить про ефективність використання гальванічного струму щільністю 0,03-0,05 мA/см². Наведені матеріали свідчать про перспективність використання прикладної теорії інорормації в медико-біологічних дослідженнях. Теорію інфрормації можна застосовувати для визначення чутливості біохімічних систем до фрізичних фракторів, встановлення оптимального діапазону їх дії та оцінки ефрективності медичної реабілітації при різних захворюваннях.
Theory of information and its application in medical rehabilitation

\section{S. Kylivnyk, V. L. Smirnova, N. Ya. Panchyshyn}

M. Pyrohov Vinnytsia National Medical University

I. Horbachevsky Ternopil National Medical University

e-mail:smirnova@tdmu.edu.ua

Summary. The development of an effective medical rehabilitation system, taking into account the current level of public health, can undoubtedly be attributed to the most important medical and social tasks of modern health care. The role of rehabilitation in practical medicine is becoming increasingly important. Until recently, rehabilitation as a process of implementation of a set of measures aimed at restoring the social and professional status of a disabled person has been used mainly by social services. However, in recent decades, with the growth of chronic pathology, it has become more in demand in the medical field.

The aim of the study - to learn and summarize the results of information research on the effectiveness of medical rehabilitation at biochemical and biophysical levels.

Materials and Methods. The information method and the mathematical apparatus of information theory were used.

Results. Reducing redundancy creates a risk of light information breakage and disruption for the biological system. When the redundancy increases, the rate of information transfer decreases. Excessive increase in redundancy causes the channels to be overloaded with excessive messaging, which reduces the amount of new information received by the receiver per unit of time over a given communication channel, so that with very large redundancies the information system loses its efficiency, lability and becomes more inert.

Conclusions. Information characteristics can be used as quantitative criteria for evaluating the effectiveness of treatment and selecting the best methods. Experience in the clinical use of galvanization and drug electrophoresis indicates the efficiency of using galvanic current with a density of $0.03-0.05 \mathrm{~mA} / \mathrm{sm}^{2}$. The given materials testify to the prospect of using applied information theory in biomedical research. Information theory can be applied to determine the sensitivity of biochemical systems to physical factors, to determine the optimal range of their action and to evaluate the effectiveness of medical rehabilitation for various diseases. 
Ключові слова: інформаціологічні дослідження; медична реабілітація.

\section{ВСТУП}

Медична реабілітація, відповідно до реабілітаційного циклу, включає оцінювання з визначенням реабілітаційних цілей, призначенням реабілітації та оцінку індивідуальних результатів [1]. Це вимагає додаткового багатомірного оцінювання фрункціонування та застосування IT-технологій [2]. Результати першого досвіду застосування теорії інфрормації для аналізу біохімічних систем підтвердили його перспективність [3-5].

П. Ф. Колісник та співавт. розробили та впровадили семирівневу систему медичної реабілітації, есрективність якої підтвердили на практиці [6]. Біохімічний та біофізичний рівні $є$ частиною цієї системи. Інформаціологічні моделі фрункціональних систем організму та їх роль у прийнятті клінічних рішень наведено в цьому дослідженні [7].

В. С. Улащик використав математичний апарат теорії інформації для характеристики дії фрізичних фракторів на деякі біохімічні системи організму та використання інформаційних показників для кількісної оцінки есрективності застосовуваних лікувальних фракторів та вибору їх оптимальних дозувань.

Для розрахунку інформаційних характеристик використано як власні дані автора, так і результати досліджень інших, які обмежились визначенням двох основних інформаційних показників - ентропії (H біт) та надлишковості (R \%) [7].

Метою дослідження було вивчити та узагальнити результати інсормаційних досліджень ефективності медичної реабілітації на біохімічному та біосрізичному рівнях.

\section{МАТЕРІАЛИ I МЕТОДИ}

Використано інформаціологічний метод та математичний апарат теорії інформації.

\section{РЕЗУЛЬТАТИ ТА ОБГОВОРЕННЯ}

ще у 1955 р. Herdan [8] довів, що для узагальненої характеристики білкового спектра крові можливе використання ентропії. Він розрахував ентропію білкового спектра у здорових людей та знайшов довірчі межі показника: $\mathrm{H}=1,545 \div 1,805$ біта.

Наведемо спосіб розрахунку ентропії білкового спектра. Скористаємось для цього даними з таблиці, запозиченої з відомої праці Rapoport [9]. У цю таблицю додано колонку з даними, необхідними для розрахунку ентропії вірогідності Р для кож-
Key words: informational research; medical rehabilitation.

ної фрракції, тобто це частки, які в сумі складають одиницю (сума вірогідності несумісних наслідків подій дорівнює одиниці).

\begin{tabular}{l|c|c}
\hline \multicolumn{3}{c}{ Таблиця. Білкові фрракції сироватки крові } \\
\hline \multicolumn{1}{c|}{ Фракція } & $\%$ & $\begin{array}{c}\text { P (частка від загально- } \\
\text { го білка) }\end{array}$ \\
\hline альбуміни & $63,6 \pm 4,00$ & 0,64 \\
\hline$\alpha_{1}$-глобуліни & $4,1 \pm 0,98$ & 0,04 \\
\hline$\alpha_{2}$-глобуліни & $7,4 \pm 1,12$ & 0,07 \\
\hline$\beta$-глобуліни & $9,9 \pm 1,92$ & 0,10 \\
\hline у-глобуліни & $15,0 \pm 2,52$ & 0,15 \\
\hline
\end{tabular}

Як видно з таблиці, розрахунок Р для срракцій спрощується за рахунок переведення відсотків в частки одиниці, тобто вміст фракцій у відсотках зменшується в 100 разів.

Відносною ентропією або коефріцієнтом стискання інфрормації називають величину $\mathrm{H}$, яка є відношенням отриманої ентропії до максимальної за умови, що наслідки для усіх елементів однаково вірогідні. Так, наприклад, якщо ми зробили розрахунок ентропії білкового спектра сироватки крові, враховуючи 5 фракцій, то максимальну ентропію повинні розраховувати для 5 елементів із припущенням імовірності для кожного: $P=\frac{1}{5}=0,2$. Таким чином, для даного випадку максимальна ентропія $H_{\max }=5 \times 0,4544=2,322$. Якщо прийняти для здорових людей ентропію білкового спектра сироватки, визначену експериментально, $\mathrm{H}=1,767$, то:

$$
H=\frac{1,767}{2,322}=0,75
$$

Отриманий результат свідчить про відносний ступінь завантаження нашої системи інсрормацією відносно можливого її максимального навантаження. У даному випадку показник 0,75 означає, що це навантаження складає 75 \% від максимального, тобто система може нарощувати ентропію в межах $25 \%$. Даний результат означає, що 25 \% інформації використовується у нашій системі для підтримання порядку, організації.

При порівнянні систем або об'єктів із нерівним числом елементів потрібно користуватись не ентропіями, а ще однією інформаційною характеристикою - коефіцієнтом надлишковості або надлишковістю (R).

Для розрахунку надлишковості використовують два підходи. При розрахунку за величинами 
ентропій надлишковість обчислюють за фрормулою:

$$
R \%=\left(\frac{H_{\max }-H}{H_{\max }}\right) \times 100=\left(1-\frac{H}{H_{\max }}\right) \times 100 .
$$

При використанні числа символів у повідомленні розрахунок ведуть за фрормулою:

$$
R \%=\left(\frac{n-n_{\min }}{n}\right) \times 100,
$$

де $n$ - число символів у реальному коді;

$n_{\min }-$ число символів при оптимальному кодуванні.

Зазвичай для розрахунку надлишковості надають перевагу значенням ентропій.

У зазначених фрормулах показано, яка частка (або \%) інфрормації, яка передається, є надлишковою, порівняно з відповідною оптимальною ії̈ передачею, або оптимальним кодом, в якому кожен символ використовують із максимальним навантаженням.

Надлишковість $є$ часткою інорормації у повідомленні, яка не вносить в нього нічого нового, але забезпечує надійність передачі, особливо за наявності перешкод (шуму) в їх каналах. В умовах організму такі перешкоди особливо відчутні внаслідок виникнення та розвитку патологічного процесу, або в результаті зниження рівня адаптації організму до умов середовища, які змінились.

Надлишковість інорормації гарантує надійність її правильності й точності. Зменшення надлишковості в системі інорормації робить її вразливою до дії перешкод, які спотворюють повідомлення. В біологічних системах це призводить до дезорієнтації, неадекватного реагування, деградації саморегулювальних та самоуправляльних механізмів. Таким чином, зменшення надлишковості створює для біологічної системи небезпеку легкої інформаційної поломки та зриву передачі інорормації. При збільшенні надлишковості відбувається зменшення швидкості передачі інсрормації. Надмірне зростання надлишковості веде до того, що канали перевантажуються надмірною передачею повідомлень, що зменшує кількість нової інорормації, яку отримує приймач за одиницю часу з даного каналу зв'язку. Тому при дуже великій надлишковості система інфрормації втрачає свою ефективність, лабільність і стає більш інертною.

Тому залежно від вимог до швидкості передачі інфоормації у різних системах зв'язку, які фрункціонують в організмі, повинні спостерігатись різні рівні надлишковості, які б відповідали цим вимогам.

Хвороба, старіння, впливи надзвичайних та несприятливих зовнішніх фракторів створюють шум в інорормаційних системах організму, що, у свою чергу, поглиблює порушення регуляторних механізмів організму, призводить до неадекватних та парадоксальних реакцій у відповідь. Інформаційний шум призводить до підвищення невизначеності прийнятої інформації відносно переданої, тобто до зростання ентропії повідомлення, створюючи неоднозначність (ненадійність, еквівокацію) отриманої та відправленої інфрормації.

щоб краще зрозуміти вплив шуму на передачу інформації, розглянемо схему системи зв'язку (схема). Система зв'язку, яка здійснює передачу інорормації, складається із джерела, передавача, каналу зв'язку, приймача та адресата. Джерело та передавач утворюють вхід у систему, а приймач та адресат - вихід із неї.

Позначаючи вхід через х, а вихід через у, можна дати позначення для шести функцій, які характеризують передачу інфрормації за системою зв'язку:

$H(x)$ - ентропія входу;

$H(y)$ - ентропія виходу;

$H(x, y)$ - сумісна ентропія входу і виходу;

$H(y / x)$ - умовна ентропія - неоднозначність виходу; входу;

$H(x / y)$ - умовна ентропія - неоднозначність

$J(x, y)$ - передана інформація

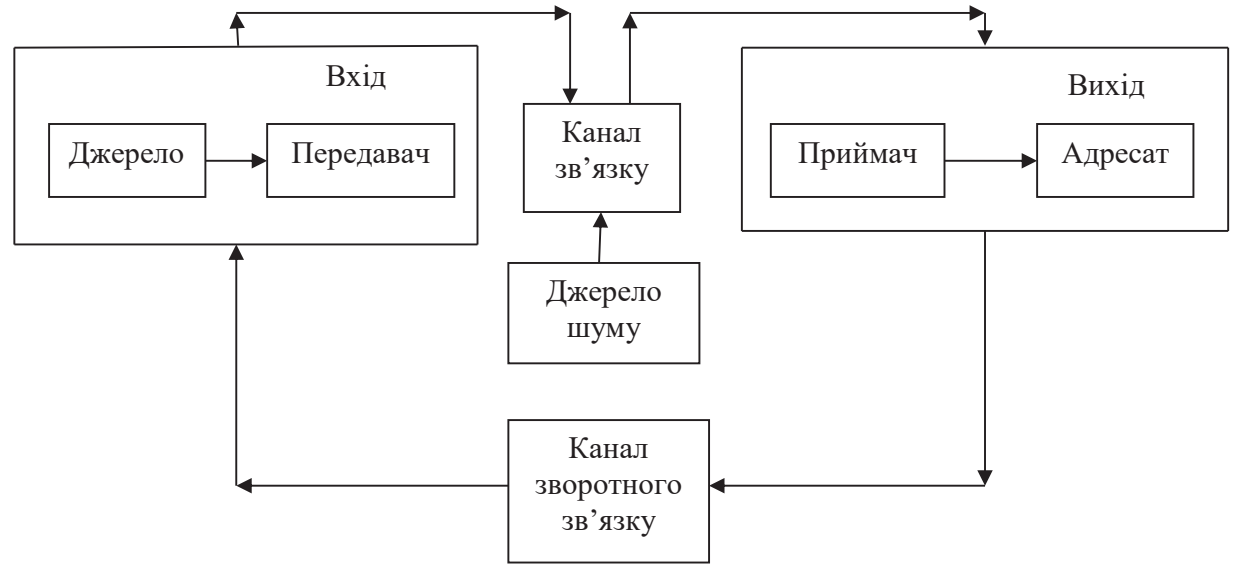

Схема. Системи зв'язку. 
Співвідношення між цими фрункціями може бути представлено у вигляді графіка Г. Кастлера [10]. Було встановлено, що:

$H(x, y)=H(x)+H(y / x)=H(y)+H(x / y)=$ $H(x)+H(x / y)$, також

$J(x, y)=H(x)-H(x / y)=H(y)-H(y / x)=$ $H(x, y)-[H(x / y)+H(y / x)]$.

У каналі зв'язку за наявності шуму $H(x / y)>0$, a $J(x, y)<H(x)$. В каналі, вільному відшуму, $H(x / y)=0$ i $H(y, x)=0$. Тому, $J=H(y)=H(x, y)$.

Вираз $H(x, y)=H(x)+H(y / x)=H(y)=H(x / y)$, по суті, $€$ математичним фрормулюванням десятої теореми Шеннона (теорема передачі інформації у каналі з шумом). У викладі Г. Кастлера [10] вона звучить так: якщо деяку кількість інформації потрібно передати з ідеальною надійністю при наявності шуму, то необхідно забезпечити таку кількість надмірної інформації, яка буде дорівнювати кількості ненадійності (еквівокації), викликаної шумом.

Як відмічає Шеннон [11], з цього випливає, що умовна ентропія $H(x / y)$ - це та кількість додаткової інфрормації, яка має бути витрачена на корекцію інфрормації, яка приймається для попередження ії спотворення. При цьому, якщо пропускна спроможність каналу корекції менше потреби в додатковій $H(x / y)$, то довершена корекція інфрормації, яка передається, буде неможлива. Під пропускною спроможністю каналу зв'язку розуміють максимально можливу швидкість передачі:

$$
C=\lim _{T \rightarrow} \frac{[H(x)-H(x / y)] \max }{T} .
$$

При цьому швидкість передачі інформації можна виражати в бітах (через ентропію) на 1 с або на один символ [12]. Останній варіант дозволяє зв'язати швидкість передачі з надлишковістю (R) та відносною ентропією (H). Кастлер [10], посилаючись на принцип Данкова, відмічає, що останній належать до «економіки» передачі біологічної інформації. Надлишковість інсрормації потребує додаткових матеріальних затрат. Унаслідок цього в боротьбі за існування організм не може безмежно збільшувати надлишковість для ефрективної боротьби 3 інфрормаційним шумом. Він повинен накопичити лише оптимальну кількість надлишкової інфрормації, яка забезпечить існування організму. За Данковим [13], будь-який організм наближається до цього оптимуму. 3 цього можна зробити висновок, що кожен організм володіє обмеженими запасами надлишкової інформації і, унаслідок цього, його опірність інформаційному шуму не безмежна. Вичерпання запасів надлишкової інформації призводить до неможливості корегувати шум до оптимального рівня. Це, у свою чергу, створює загрозливі наслідки для гомеостазу організму.

Ashby [14] вперше зазначив, що в десятій теоремі Шеннона міститься кібернетичний принцип регуляції гомеостазу. Відхилення від параметрів гомеостазу можуть свідчити про порушення інфрормаційних механізмів організму. При передачі інформації у системах зв'язку організму в нормі вважається, що сигнали, відправлені джерелом, досягають приймача без відчутних шумових спотворень, чим забезпечується однозначність інфрормації на вході та на виході системи.

Тому в нормі інорормаційні фрункції тотожні:

$$
H(x)=H(y)=H(x, y)=J(x, y) .
$$

Таким чином, інфрормація, відправлена передавачем, буде дорівнювати отриманій приймачем. У нормальному (здоровому) стані організму ентропія будь-якої системи може бути прийнята за ентропію входу або виходу, або сумісну:

$$
H_{\text {норм }}=H(x)=H(y)=H(x, y) .
$$

При порушенні нормального статусу організму (хвороба, стрес тощо) інорормація буде передаватись по каналу зв'язку з шумом, що завадить ідентичності переданої і отриманої інорормації. До ентропії входу буде додаватись ненадійність (еквівокація) виходу, а до ентропії виходу - ненадійність входу.

Отже, ентропія системи при патології (H патол.) є сумнівною ентропією входу та виходу в умовах впливу інфрормаційного шуму:

$$
H_{\text {патол }}=H(x, y)=H(x)+H(y / x)=H(y)+H(x / y) .
$$

Оскільки $H_{\text {норм }}=H(x)+H(y)$, можна вважати, що:

$$
H_{\text {патол }}-H_{\text {норм }}=H(y / x)=(x / y) .
$$

Таким чином, різниця ентропій патології і норми дає величину ненадійності (еквівокації) передачі інорормації при патології. Враховуючи те, що еквівокація може бути зумовлена витратами надлишковості, різниця надлишковості в нормі - патології зв'язана з ентропіями таким чином:

$$
\begin{gathered}
R_{\text {норм }}-R_{\text {патол }}=\frac{H_{\text {патол }}-H_{\text {норм }}, \text { звідки }}{H_{\max }} \\
\left(R_{\text {норм }}-R_{\text {патол }}\right) \times H_{\max }=H_{\text {патол }}-H_{\text {норм }}=H(x / x)
\end{gathered}
$$

3 цього випливає, що еквівокація пропорційна різниці надлишкової норми і патології, а також максимальній ентропії. Таким чином, для багатокомпонентних систем еквівокація буде більшою, ніж для малокомпонентних.

Інформаційні властивості найбільш притаманні речовинам із специфічними властивостями та біологічними функціями. До них відносять перш за все білки, які утворюють в організмі складну багатокомпонентну систему, зміни в якій приводять до 
порушення інорормації. В. С. Улащик дав інфрормаційну оцінку змін у білковому спектрі сироватки крові й печінки кроликів з експериментальним атеросклерозом під впливом мінеральних ванн різного складу. Як видно із дослідів, розвиток атеросклерозу супроводжувався несприятливими змінами в системі білків, про що свідчать збільшення інорормаційної ентропії та зменшення надлишковості. Призначення курсу ванн приводило до помітного зниження ентропії і підвищення надлишковості, що є показником росту впорядкованості в білкових системах крові та печінки.

Найефективнішим виявилось використання хлоридно-натрієвих ванн 3 мінералізацією 10 г/л. До такого ж висновку, який ґрунтується на багаточисельних біохімічних та морфрологічних дослідженнях, прийшов і Д. Г. Григор'ян [15]. Таким чином, простий розрахунок інформаційних характеристик білкового спектра дає можливість зробити висновок про терапевтичну ефективність того чи іншого бальнеологічного комплексу, що узгоджується з результатами трудомістких клініко-біохімічних досліджень.

Використання при вищеприведеній патології мікрохвильового опромінення спричинило несприятливі зміни в організмі тварин [15]. Результати інорормаційної оцінки даних підтвердили висновок авторів: мікрохвилі приводять до збільшення ентропії і зменшення надлишковості інорормації в

\section{СПИСОК ЛІТЕРАТУРИ}

1. Біла книга з фрізичної та реабілітаційної медицини в Європі // Український журнал фрізичної та реабілітаційної медицини. - 2018. - № 2. - С. 113-127.

2. Застосування медичної інфрормаційної системи в організації та управлінні реабілітаційно-відновлювальним лікуванням постінсультних хворих в санаторно-курортній установі : методичні рекомендації / О. П. Мінцер, С. М. Злепко, І. І. Хаїмзон та ін. - К., 2012. - 20 с.

3. Авралева А. И. Белково-коллоидные сдвиги в сыворотке крови у больных с заболеваниями сердечнососудистой системы при недостаточности кровообращения : авторефр. дисс. на соиск. учен. степ. канд. мед. наук / Витеб. гос. мед. ин-т. - Минск, 1963. - 24 с.

4. Бандарин В. А. Кибернетика в медицине / В. А. Бандарин. - Минск, 1968.

5. Улащик В. С. В кн.: Актуальные вопросы невропатологии и нейрохирургии / В. С. Улащик. - Минск, 1972. Вып. 5. - С. 235-242.

6. Колісник П. Ф. Проблеми підготовки лікарів 3 питань медичної реабілітації / П. Ф. Колісник // Вісник системі білків. Зазначені зміни інформаційних характеристик свідчать про порушення в системі білкового гомеостазу та деградації.

У лабораторії В. С. Улащика вивчали вплив мікрохвиль на перебіг токсичного гепатиту в кроликів. Використовували мікрохвилі потужністю 2; 5; 10; 15 Вт та чергування потужностей 5 і 10 Вт. Останній варіант виявився найефективнішим. Відбулось майже повне відновлення впорядкованості в системі білків та значно підвищились надійність ії фрункціонування.

\section{вИСНОВки}

1. Інфрормаційні характеристики можна використовувати в якості кількісних критеріїв оцінки еорективності лікування та вибору найоптимальніших методів.

2. Досвід клінічного використання гальванізації та лікарського електрофорезу свідчить про ефективність використання гальванічного струму щільністю 0,03-0,05 мA/см².

3. Наведені матеріали є перспективними у використанні прикладної теорії інформації в медикобіологічних дослідженнях.

4. Теорію інорормації можна застосовувати для визначення чутливості біохімічних систем до фрізичних фракторів, встановлення оптимального діапазону їх дії та оцінки ефективності медичної реабілітації при різних захворюваннях.

Вінницького національного медичного університету. 2013. - T. 17, № 2. - С. 441-445.

7. Килівник В. С. Інфрормаціологічні моделі функціональних систем організму та їх роль у прийнятті клінічних рішень / В. С. Килівник, О. О. Галаченко, І. В. Кузьмін // Вісник соціальної гігієни та організації охорони здоров'я України. - 2009. - № 4. - С. 86-90.

8. Herdan G. // . Klin. Wschr. - 1955. - Vol. 33 (21/22). - P. 538.

9. Rapoport S. M. Medizinische Biochemie / S. M. Rapoport. - Berlin; 1969.

10. Кастлер Г. В. Теория инорормации в биологии / Г. В. Кастлер. - М., 1960. - 183 с.

11. Шеннон К. Работы по теории инорормации и кибернетике / К. Шеннон. - М., 1963.

12. Кастлер Г. В. Возникновение биологической организации / Г. В. Кастлер. - М., 1967.

13. Dancoff S. M. In information theory in biology urbana / S. M. Dancoff, H. Quastler. - 1958.

14. Ashby W. R. Cybernetica. - 1958.

15. Григорьян Д. Г. Вопросы бальнео- и физиотерапии (труды ЦНИИКИФ) / Д. Г. Григорьян. - М., 1970. 


\section{REFERENCES}

1. [A white book of physical medicine and rehabilitation medicine in Europe]. Ukr. zhurn fiz i reab med. 2018;2: 11327. Ukrainian

2. Mintser OP, Zlepko SM, Khaimzon II, Azarkhov OYu, Laduba YuM, Babintseva LYu, Kylivnyk VS. Involvement of the medical information system in the organization and management of the rehabilitation and rehabilitation of the post-stroke illnesses in the sanatorium-resort setting. [3aстосування медичної інформаційної системи в організації та управлінні реабілітаційно-відновлювальним лікуванням постінсультних хворих в санаторно-курортній установі: методичні рекомендації] Kyiv; 2012. Ukrainian.

3. Avraleva Al. Protein-colloidal changes in blood serum in patients with diseases of the cardiovascular system with circulatory failure. Extended abstract of Candidate's thesis. Minsk; 1963. Russian.

4. Bandarin VA. Cybernetics in medicine. [Кибернетика в медицине] Minsk; 1968. Russian.

5. Ulashchik VS. Actual issues of neuropathology and neurosurgery. [Актуальные вопросы невропатологии и нейрохирургии] Minsk; 1972. Russian.
6. Kolisnyk PF. [Problems of training physicians in medical rehabilitation]. Visn Vinn nats univer. 2013;2: 44145. Ukrainian.

7. Kylivnyk VS, Halachenko OO, Kuzmin IV. Information models of organism's functional systems and their role in clinical decision making. Visn sots hihiieny i orhanizatsii okhorony zdorovia. 2009;4: 86-90. Ukrainian.

8. Herdan G. Klin Wschr. 1955;33(21/22): 538.

9. Rapoport SM. Medizinische Biochemie. Berlin; 1969.

10. Kastler GV. Information Theory in Biology. [Теория информации в биологии] Moscow; 1960. Russian.

11. Shennon K. Works on information theory and cybernetics. [Работы по теории информации и кибернетике] Moscow; 1963. Russian.

12. Kastler GV. The emergence of a biological organization. [Возникновение биологической организации] Moscow; 1967. Russian.

13. Dancoff SM, Quastler H. In Information Theory in Biology Urbana; 1958.

14. Ashby WR. Cybernetica; 1958.

15. Grigor'yan DG. Questions of balneotherapy and physiotherapy. [Вопросы бальнео- и фризиотерапии (труды ЦНИИКИФ)] Moscow; 1970. Russian.

Отримано 02.09.19 